\title{
Migration as a Factor of the Sustainable Economic Development
}

\author{
P. Kurmaiev ${ }^{1}$, L. Seliverstova ${ }^{2}$, N. Husarevych ${ }^{2}$, P. Kolisnichenko ${ }^{1}$
}

\begin{abstract}
The problem of the interplay between migration and the achievement of the sustainable development goals is one of the main topics in modern scientific debate. The theoretical basis of the study is the understanding of migration as a continuous process caused by the interaction of a complex of factors, the result of which is the formation of a new quality globalized society. The methods used were: Comparative analysis and Content analysis. The authors note that the effectiveness of national policies depends significantly on the extent to which global migration trends are taken into account. The main factors that determine the dynamics of migration flows are identified in the article. The dominance of economic and security-humanitarian motives for migration is mentioned. It is noted that modern migration processes as a whole have a positive impact on the achievement of sustainable development goals. In modern world, migration is the driver of the country's demographic, economic and socio-cultural situation. For most countries in the world, the main objectives of immigration policy are to meet the need for labor, balance the labor markets, reduce the rate of depopulation and an aging population. The research made it possible to identify the types of immigration policy of governments of the world countries and their characteristics. The authors indicate that $73 \%$ of governments search to increase or maintain the current level of immigration of highly skilled workers. The thesis is substantiated that the impact of migrants on the wages of highly skilled workers in the country of destination is minimal. The impact of emigration on the socio-economic situation of the donor country is analyzed. The study found that emigration alone is not a destructive factor for the donor country. Significant deterioration in the country is influenced by a set of factors, among which migration is only one of them.
\end{abstract}

Keywords: migration, sustainable economic development, donor-countries

\section{Introduction}

The problem of sustainable economic development is one of the main topics in the current scientific debate. It is not so much about accelerating economic growth, but about the need to develop a new model of sustainable development that would be able to ensure the stability of socio-economic systems in the future.

Migration is a permanent process that accompanies the development of human civilization. Addressing the problems associated with international migration and using its positive results are prerequisites that contribute to achieving the goals of sustainable development.

Moving the human masses has led to changes in the destination region, sometimes with catastrophic consequences. Population migrations took place on all continents. That is why it is difficult to name a country that has not been a participant in migration processes throughout its history. Over time, the forces of migration were transformed. 
Thus, if during the great migration of peoples, predominantly, the forces of nature were determining the direction and intensity of migration, now other factors are dominant.

In the modern world, migration, being a manifestation of a secure and socio-economic policy, ultimately influences other aspects of both global and national policies: demographic, scientific, technological, environmental and others.

In the age of globalization, the effectiveness of implementing national policies depends significantly on the degree to which global migration trends are taken into account.

\section{Methodology}

The theoretical basis of the study is the understanding of migration as a continuous process caused by the interaction of a complex of factors, the result of which is the formation of a globalized society of new quality.

We used the Comparative analysis method to study migration processes in different countries and compare the indicators that characterize them.

The interpretation of scientific information obtained from various sources has led us to use the Content analysis.

We used survey results and statistical information from the following organizations: CIA (The World Factbook), International Organization for Migration, International Labor Office, United Nations, World Bank Group and others.

\section{Literature Review}

A detailed analysis of the factors that activate migration processes is given in (Castles, 2013). The author rightly points out that income inequality and security are the main causes of migration. Also, the article addresses the issues of the migration business functioning. The author has covered the infrastructure of this business and its features in sufficient detail. In our opinion, the study of problems connected with the migration business functioning is promising.

Migration as a result of political and economic transformations is discussed in (Czaika \& de Haas, 2014). The authors analyze the main trends of migration processes over the period during 1960-2000, and calculate the indicators that allow a more complete study of the features of migration processes. The article reveals the nature of modern migration policy of the countries of the world, emphasizes the priority of employment and granting of residence permits to skilled workers, wealthy persons. It is argued that current migration policies create additional vulnerabilities for migrants in the labor market.

The results of a thorough analysis of migration flows are given in (Abel \& Sander, 2014). During the analysis, the authors investigated the migration flows of 196 countries over the period during 1990-2010. The information obtained allowed us to interpret the main trends of migration, to determine the future perspective directions of migration flows.

The study of the impact of environmental change on migration processes is devoted to research (Warner, 2010). The results of the analysis of the empirical data show that environmental factors influence the dynamics of migration flows. It is noted that global changes in the environment can lead to a migration of 50 to 700 million people by 2050 . 
The author pays attention to the problems of migration management that are caused by environmental reasons.

By the Writing Team (Dao et al. 2018) the 2010 model of the world economy with sociodemographic characteristics was constructed. The results of the retrospective analysis and the model calculations showed that the main trends in migration were related to demographic changes. OECD countries' estimated forecasts indicate a significant increase in migrant flows, which will be triggered by socio-demographic factors in the countries of migrants' origin. For example, calculations show that immigration in 2016 will be $20 \%$ for the EU-15, compared to $14.6 \%$ in 2010 .

The article (Di Giovanni et al. 2014) is devoted to the study of the migration impact on global well-being. The results of the study indicate a positive impact of migration on both countries of destination and countries of migrants' origin.

Various aspects of the modern migration management system operation are discussed in (Kunz et al. 2011). The authors note that the issue of migration is becoming increasingly politicized.

At the same time, the globalization of labor markets maximizes the economic benefits of migration for all participants in the process.

The thesis that improving the efficiency of migration management is possible under the conditions of international cooperation and coordination of activities is argued.

\section{Results}

In today's world, migrants are an active part of the population. Since the beginning of the third millennium, the number of migrants has grown faster than the Earth's population.

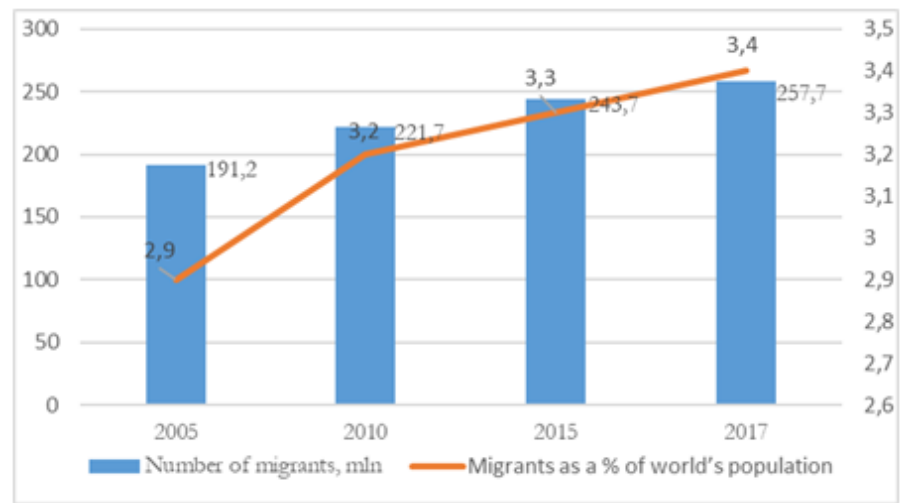

Fig. 1. Dynamics of migrant population and their share in the world's population

Source: United Nations, 2018b, World Bank Group, 2019

Thus, during 2005-2017 the population of our planet increased by $15.3 \%$ and the number of migrants increased by 34.7\%, in particular, during 2013-2017 - by 11\% (Fig. 1). This was caused by two main factors.

1. Consequences of active phase of hostilities in North, East Africa, East Asia, Eastern 
Europe. Military conflicts in these regions were accompanied by civilian casualties and ethnic cleansing. For example, military action in Côte d'Ivoire in 2010 triggered the displacement of up to 1 million people, 350,000 were displaced by ethnic cleansing in South Sudan and 160,000 were displaced by the Democratic Republic of the Congo (Birkeland, Jennings, \& Rushing, 2012). In this case, security and humanitarian motives have become dominant for the population of these regions.

2. Activation of deepening differentiation processes of countries in terms of development, first of all, economic.

Thus, during the years 1980-2016, 1\% of the highest-income earners received a $27 \%$ increase in income. At the same time, $50 \%$ of the lowest income earners received only $13 \%$ growth. Yes, 10\% of the richest people in 2016 owned $61 \%$ of national income in the Middle East, 55\% in India and Brazil, and 54\% in Sub-Saharan Africa (Alvaredo et al. 2018). Net private wealth in the richest countries rose from $200-350 \%$ of national income in 1970 to $400-700 \%$ in 2016 (Alvaredo et al. 2018).

In $2017,41 \%$ of international migrants were born in Asia, 23.7\% - in Europe, 14.6\% - in Latin America, 14\% - in Africa, 6.7\% - in North America and Oceania [17, 9]. Comparing to 2013, the structure of international migrants by country of origin has undergone significant changes. The share of countries increased in Asia and Africa, and in Europe, Latin America, North America and Oceania it decreased.

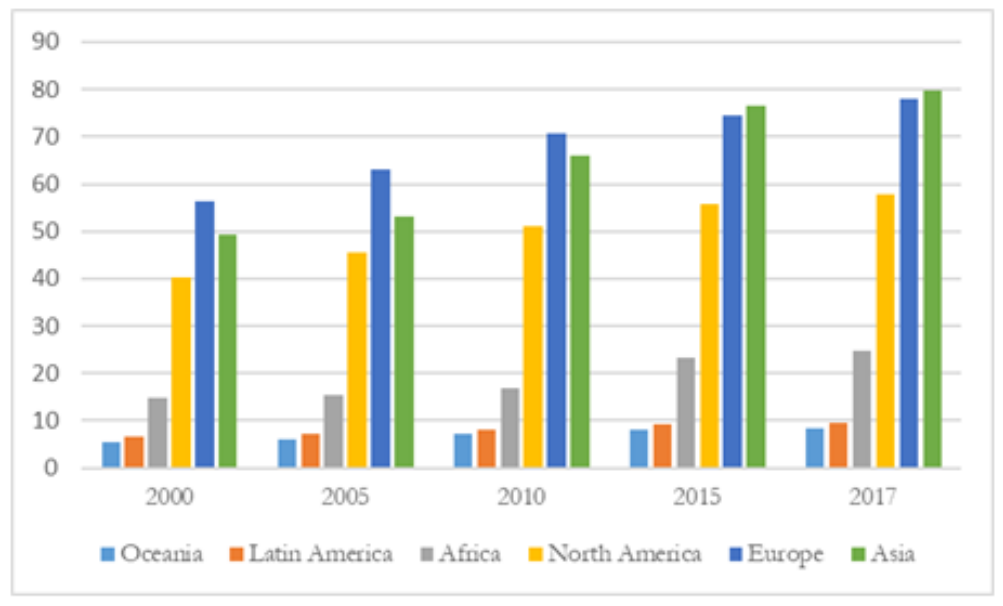

Fig. 2. Number of international migrants by major area of destination

Source: United Nations, $2018 b$

In turn, between 2000 and 2017, Asian countries received the largest number of international migrants - about 30 million (Fig. 2). 22 million migrants moved to Europe, 17 million - to North America, 10 million - to Africa (United Nations, 2018b).

In $2017,51.1 \%$ of migrants were accumulated in ten countries (United Nations, 2018b): the USA, Saudi Arabia, Germany, Russia, the United Kingdom, the United Arab Emirates, France, Canada, Australia, Spain.

Up to 7 of the above countries (the USA, Saudi Arabia, Germany, Russia, the United Arab Emirates, France, Spain), the largest number of migrants came from countries in 
the region or other geographically located countries. This behavior is caused by the limited financial resources of most of them, which makes it difficult to move between continents. Another obstacle is the complexity and danger of migration routes. For example, only during 2014-2017, according to confirmed data, more than 26.2 thousand migrants were killed (IOM, 2019).

At the same time, it is advisable to note the high proportion of migrants from South Asian countries in the total number of migrants in the countries that are the largest recipients. In Saudi Arabia and the United Arab Emirates, they are more than half of all migrants.

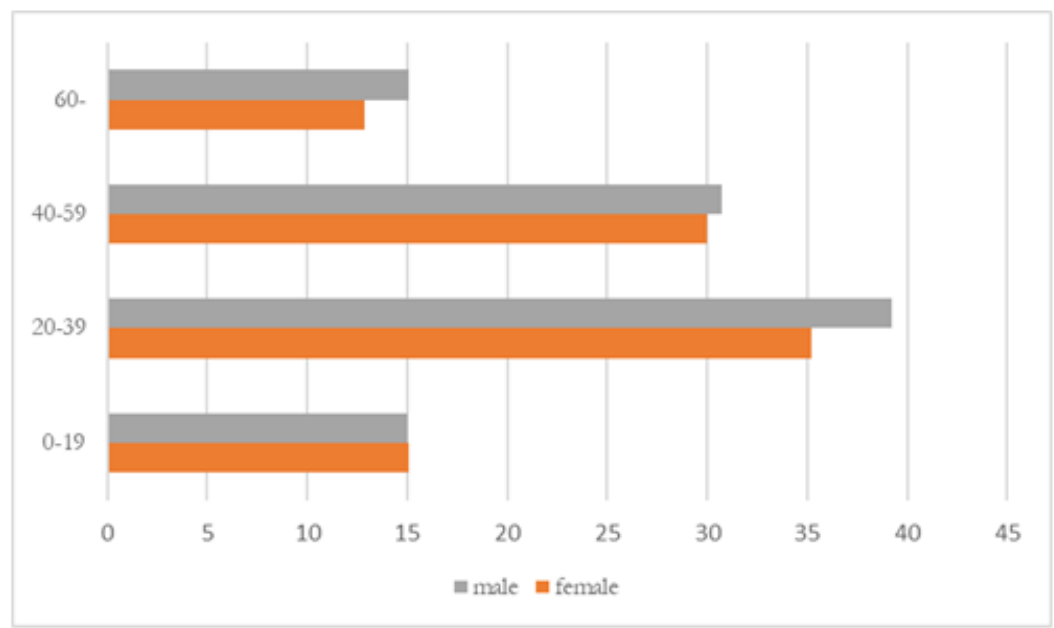

Fig. 3. Age pyramid

Source: United Nations, 2018b; McAuliffe \& Rubs (Eds), 2017

The average age of migrants in 2017 was 39.2 years. For migrants from high-income countries, it was 40.6 years, with an average income of 37.3 years, with a low income of 29.8 years (United Nations, 2018b). The age pyramid of migrants is shown in Fig. 3.

This is mainly due to the fact that residents of high-income countries (economically developed) have more opportunities for self-realization. Therefore, a migration decision is made at the age of 40-45, when the possibility of change in the country of residence is limited. The socio-economic situation in low-income countries is characterized by low levels of employment, corruption, non-compliance with labor and civil rights. Migration sentiment is quite widespread among low-income countries, as migration creates the preconditions for a secure life and self-fulfillment.

For example, in 2017, migrants living in Africa were the youngest, their average age was 30.9 years. The average age of migrants from Asia was 35.1 years, Latin America - 35.8 years, Europe - 42.6 years, Oceania - 43.9 years, North America - 44.7 years (United Nations, 2018b).

In 2017, according to ILO (ILO, 2018) migrant workers accounted for $63.6 \%$ of the total migrant population. Comparing to 2013, the number of migrant workers was growing at a slower rate than the overall number of migrants. 
$60.8 \%$ of migrant workers were concentrated in three subregions: North America $(23.0 \%)$, Northern, Southern and Western Europe (23.9\%) and Arab countries $(13.9 \%)$ (ILO, 2018).

In other subregions, respectively, there were $39.2 \%$ of migrant workers.

The concentration of labor migrants in high-income countries is observed (Fig. 4).

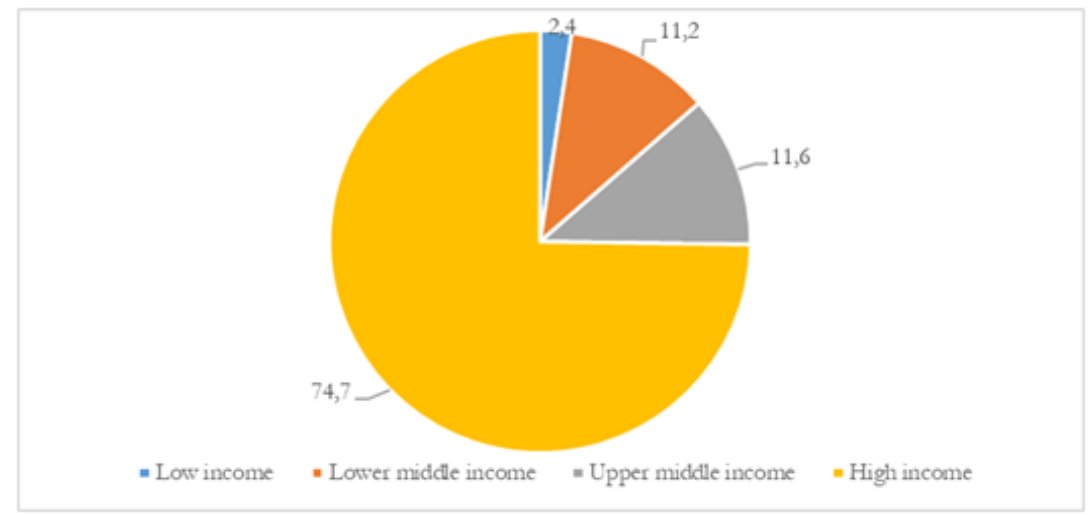

Fig. 4. Migrant workers, by sex and income level of destination countries

Source: McAuliffe \& Rubs (Eds), 2017

At the same time, during 2013-2017 there were significant changes in the concentration of migrant workers, depending on the level of economic development of the destination country.

Thus, the concentration of labor migrants in high-income countries decreased from $74.7 \%$ to $67.9 \%$ over the indicated period, with their share in higher-than-average income countries rising from $11.7 \%$ to $18.6 \%$.

Migrant share in below-average income countries declined from $11.3 \%$ to $10.1 \%$ and in low-income countries increased from $2.4 \%$ to $3.4 \%$ (ILO, 2018).

It is appropriate to agree with (OECD / ILO, 2018) that the transformation of the regional concentration of migrant workers is carried out by higher economic growth in the economic development of income countries, especially if destination countries and migrant donor countries share common borders or are geographically close.

It should also be borne in mind that some economically developed countries, such as the United States, Germany, Italy, are significantly changing migration policy in the direction of its complication.

Nowadays, there is a plurality of opinions regarding the impact of migrants on the labor market and wages. For example, scientists (Dustmann, Frattini \& Preston, 2012) point to the positive impact of a growing number of migrants on wage dynamics. At the same time, there are other opinions on this topic. For example, researchers from the United States (Friedberg \& Hunt, 1995) have found that a 10\% increase in migrants leads to a decrease in wages of no more than 1\%. Similar results were given from British scientists (Nickell \&Saleheen, 2015) indicating a slight negative impact of migration. The team of authors (Oladi \& Beladi, 2007) points out that the migration of low-skilled labor has a negative impact on the wage pay for both low-skilled and high-skilled workers. 
In our view, the increase in the number of migrant workers certainly has an impact on the wage dynamics of low-skilled workers. Higher education documents require the majority of migrants to be certified or not recognized at all in the country of destination. This creates an additional burden on the low-skilled labor market as migrants with higher education are forced to perform low-skilled jobs.

For the reasons outlined above, the impact of migrants on the wages of highly skilled workers is minimal.

In the context of globalization, immigration policy is an important component of national development strategies. Over time, its role will only increase as it is a driver of the country's demographic, economic and socio-cultural situation.

That is why, for 68\% of the world governments (United Nations, 2016; United Nations, 2017a), immigration policy is addressing the need for labor and balancing labor markets. At the same time, $28 \%$ of governments, through immigration policy, implement measures aimed at depopulation and reducing the rate of population aging.

For example, it is advisable to agree with the findings (United Nations, 2018b) that in the countries of North America, Europe, Oceania, the dependence on old age would be higher in the absence of migration. That means that positive net migration will help reduce the old-age dependency ratio in most economically developed countries.

At the same time, migration reduces the depopulation of the working age population in economically developed regions. The results of the scenario forecasting (United Nations, $2017 \mathrm{~b}$ ) indicated that a decrease in net migration would result in a decrease in the working population in North America by $16 \%$, Oceania by $15 \%$ and Europe by $8 \%$. In some countries of the Arab world (UAE, Qatar, Bahrain) there can be a catastrophic situation in the labor market, since, in the absence of migration of working age population, it will be reduced by $53 \%, 48 \%$ and $45 \%$ respectively (United Nations, 2017b).

In our opinion, it is advisable to identify several types of immigration policies of governments in the world.

1. The greatest assistance is realized for the representatives of high-demand professions / occupations whose activities do not require additional training / retraining. This applies not only to highly skilled workers (businessmen, IT workers, athletes, industry scientists), but also to low-skilled workers (builders, cleaners).

2. Loyalty is implemented for workers who can work in the country of destination after successful completion of additional training / retraining, passing language proficiency exams. This group includes health professionals, educators and other categories, depending on the labor market demand of the country of destination.

3. Restriction. It is conducted in relation to the representatives of professions / occupations, the demand for which is absent in the country of destination. In this case, the migrants do not work in education.

That means that today the politics of host governments is characterized by selectivity in immigration policy. Overall, $85 \%$ of governments search to increase or maintain the current level of immigration of highly-skilled workers. At the same time, only $4 \%$ of governments are active in reducing immigration of highly-skilled workers, and 11\% are not pursuing appropriate policies (United Nations, 2017a).

Since 2009, the Blue Card project has been operating in the EU (with the exception of 
the United Kingdom, Denmark, Ireland), with the aim of meeting the needs of highlyskilled workers from non-EU countries.

Immigration assistance programs are implemented not only to attract highly-skilled workers. For example, in Israel, immigration issues are addressed by the Ministry of Aliyah and Integration, as well as by the non-profit organizations "The Jewish Agency for Israel" and "Nefesh B'Nefesh", regardless of their level of qualification. The Government of Canada is also pursuing an active immigration policy to attract immigrants of various skill levels through the Atlantic Immigration Pilot and Rural and Northern Immigration Pilot programs.

In order to attract low-skilled workers, the Government of South Korea has been implementing a series of Employment Permit System (EPS) activities since 2004. The program operates on the basis of intergovernmental agreements with 16 countries in the region.

\section{Donor-countries. Look Form the Other Side}

Using the statistics (CIA, 2018), we selected 10 countries that had the highest negative NMR during 2013-2017. These include: Tonga, Samoa, Saint Vincent and the Grenadines, Federated States of Micronesia, Moldova, Sao Tome and Principe, El Salvador, Lesotho, Eritrea, Somalia.

During 2013-2017, NMR values in all the above countries tended to improve.

The main causes of migration from these countries are economic. Permanent hostilities continue in Eritrea and Somalia, an additional factor that stimulates migration.

All the above countries have a per capita income level below the world average. In particular, according to the World Bank, three per capita income levels are higher than average in the three island countries (Tonga, Samoa and Saint Vincent and the Grenadines).

5 countries have below-average per capita income levels. These include: Micronesia, Moldova, Sao Tome and Principe, El Salvador, Lesotho.

Two countries (Eritrea, Somalia) have low per capita incomes.

In order to study the impact of NMR on individual macroeconomic indicators, we have divided the above countries into three groups, based on the World Bank's per capita income level (World Bank, 2018d).

In the first group, in Samoa and Saint Vincent and the Grenadines, the decrease in the negative NMR value during 2013-2017 was accompanied by a $2 \%$ and $7.7 \%$ increase in GDP per capita, and a decrease of $4.7 \%$ in Tonga (World Bank, 2018b). The share of transfers from abroad in the GDP of the countries of this group ranged from $5 \%$ in Saint Vincent and the Grenadines, $16.3 \%$ in Samoa to 35.9\% in Tonga (World Bank, 2018a; 2018c).

The tourism industry is the core sector of Saint Vincent and the Grenadines. The increase in tourism flows and tourism revenues during 2013-2017 largely determined the positive dynamics of GDP per capita.

The economic situation in Samoa was characterized by a decrease in the annual volume of attracted foreign investments and transfers from abroad. The drivers of positive GDP dynamics were tourism and agriculture. In 2017, Samoa ranked third in Pacific Island 
Countries (Annual Review, 2018).

The decrease in GDP per capita in Tonga occurred at the same time as a significant decrease in the annual volume of attracted foreign investment, which was not offset by an increase in remittances from abroad. Also, during 2013-2017 there was a decrease in world prices for major export positions.

In the second group, negative GDP per capita dynamics in 2013-2017 occurred only in Lesotho. In the rest of the countries (Federated States of Micronesia, Moldova, Sao Tome and Principe, El Salvador), GDP per capita has increased, with growth rates exceeding 10\% in 2013-2017 in Sao Tome and Prince and El Salvador (World Bank, 2018b).

In three countries of the group (Federated States of Micronesia, Sao Tome and Principe, El Salvador), the volume of attracted foreign investments increased, in Moldova and Lesotho it decreased (UNCTAD, 2018).

The amount of annual transfers from abroad during 2013-2017 has increased in the Federated States of Micronesia and El Salvador. In Moldova, the Federated States of Micronesia, El Salvador and Lesotho, the share of transfers exceeds 5\% of GDP (World Bank, 2018a).

Despite the high rate of migration, the unemployment rate exceeded 10\% in three countries (Federated States of Micronesia, Sao Tome and Principe, Lesotho), which did not contribute to the improvement of migration sentiment. For example, in 2016-2017, the Federated States of Micronesia had one of the highest negative NMR values worldwide (CIA, 2018).

The third group includes two African countries - Eritrea and Somalia. During 2013-2017, the negative NMR value in Somalia decreased by 4 points, which was characterized by the highest rate of improvement of this indicator among all countries in the three groups. However, Somalia's GDP per capita decreased by 1.5\% (World Bank, 2018b). At the same time, Eritrea's GDP per capita has increased. Foreign investment increased over the period in both countries (World Bank, 2018a). There is no reliable data on transfers to countries in this group.

\section{Conclusions}

The history of human civilization is inextricably linked to migration.

Globalization and the results of scientific and technological progress have created the preconditions for facilitating the movement of people. The main causes of migration remain security and humanitarian and those related to the deepening of the differentiation of countries in terms of economic development.

In our view, there is a direct link between migration and the successful achievement of sustainable development goals.

It is possible to find in the scientific literature that migration has a negative impact on the socio-economic situation in the donor country (origin of migrants). Yes, migration reduces the size of a potentially active population of the country, but on the other hand, migration allows a particular person to have a chance for a better life, to realize him.

The coverage of migrant issues is closely linked to the provisions of the Universal Declaration of Human Rights. 
The survey showed a 34.7\% increase in the number of migrants during 2005-2017. The main destinations for migration are countries in Asia, Europe and North America. In turn, $60.8 \%$ of migrant workers were concentrated in the following subregions: North America, Northern, Southern and Western Europe and the Arab world.

Modern migration processes in general have a positive impact on the achievement of sustainable development goals. Most countries in the world are searching to increase or maintain the current level of immigration of highly skilled workers.

The study showed that population emigration is not a destructive factor for the donor country.

Significant deterioration in the country is influenced by a set of factors, among which migration is only one of them.

Out of the 10 countries that had the highest negative NMR during 2013-2017, only 3 recorded a decline in GDP per capita. In this case, GDP is a general indicator of the economic development of the country for a certain period. The Human Development Index has increased in all countries, with 4 countries out of 9 (no information available in Somalia) having a high Human Development Index (United Nations, 2018a).

The results of the analysis show that the root causes of migration will determine the dynamics of migration flows in the short and medium term. Therefore, the achievement of the Sustainable Development Goals will be closely linked to the formation of effective mechanisms for managing migration processes.

\section{References}

Abel, G. J., \& Sander, N. (2014). Quantifying Global International Migration Flows. Science, 343(6178), 15201522. doi:10.1126/science.1248676.

Alvaredo, F., Chancel, L., Piketty, T., Saez, E., \& Zucman, G. (Eds.). (2018). World inequality report 2018. Belknap Press.

Annual review of visitor arrivals in Pacific island countries South (2018). Suva: Pacific Tourism Organization

Birkeland, N., Jennings, E., \& Rushing, E. (2012). Internal Displacement Global Overview 2011: People internally displaced by conflict and violence. Internal Displacement Monitoring Centre.

Castles, S. (2013). The Forces Driving Global Migration. Journal of Intercultural Studies, 34(2), 122-140. doi:10.1080/07256868.2013.781916

Central Intelligence Agency (CIA) (2018). The World Factbook. Net migration rate. Retrieved from https://www.cia.gov/library/publications/the-world-factbook/rankorder/2112rank.html. Accessed 10/10/2019

Czaika, M., \& de Haas, H. (2014). The Globalization of Migration: Has the World Become More Migratory? International Migration Review, 48(2), 283-323. https://doi.org/10.1111/imre.12095

Dao, T., Docquier, F., Maurel, M., \& Schaus, P. (2018). Global migration in the 20th and 21st centuries: the unstoppable force of demography 〈hal-01743799〉, Retrieved from https://hal.archivesouvertes.fr/hal-01743799/. Accessed 10/10/2019

Di Giovanni, J., Levchenko, A. A., \& Ortega, F. (2014). A Global View Of Cross-Border Migration. Journal of the European Economic Association, 13(1), 168-202. doi:10.1111/jeea.12110

Dustmann, C., Frattini, T., \& Preston, I. P. (2012). The effect of immigration along the distribution of wages. Review of Economic Studies, 80(1), 145-173.

Friedberg, R. M., \& Hunt, J. (1995). The impact of immigrants on host country wages, employment and growth. Journal of Economic perspectives, 9(2), 23-44.

International Labour Organization (ILO) (2018). ILO global estimates on migrant workers: Results and methodology. Geneva: International Labour Office.

International Organization for Migration (IOM) (2019). Missing Migrants. Retrieved from https://missingmigrants.iom.int/. Accessed 10/10/2019 
Kunz, R., Lavenex, S., \& Panizzon, M. (Eds.) (2011). Multilayered migration governance: The promise of partnership. Taylor \& Francis. DOI: https://doi.org/10.4324/9780203827833

McAuliffe, M., \& Ruhs, M. (Eds) (2017). World migration report 2018. Geneva: International Organization for Migration.

Nickell, S., \& Saleheen, J. (2015). The impact of immigration on occupational wages: evidence from Britain. Staff Working Paper No. 574. Retrieved from SSRN: https://ssrn.com/abstract $=2706493$ or http://dx.doi.org/10.2139/ssrn.2706493

OECD/ILO (2018). How Immigrants Contribute to Developing Countries' Economies. Paris: OECD Publishing. http://dx.doi.org/10.1787/9789264288737-en

Oladi, R., \& Beladi, H. (2007). International migration and real wages. Economics Bulletin, 6(30), 1-8.

UNCTAD (2018). FDI inflows, by region and economy, 1990-2018. Retrieved from https://unctad.org/Sections/dite_dir/docs/WIR2019/WIR19_tab01.xlsx. Accessed 10/10/2019

United Nations (2016). World Population Policies Database: 2015 Revision. NY: United Nations

United Nations (2017a). Policies on international migration. Population facts. 2017/7. NY: United Nations

United Nations (2017b). Migration and population change - drivers and impacts. Population facts. 2017/8. NY: United Nations

United Nations (2018a). Human Development Index. Retrieved from http://hdr.undp.org/en/content/human-development-index-hdi. Accessed 10/10/2019

United Nations (2018b). International migrant stock: The 2017 revision. Retrieved from https://www.un.org/en/development/desa/population/migration/data/estimates2/estimates17. asp. Accessed 10/10/2019

United Nations. (2018c). International Migration Report 2017-Higblights. NY: United Nations.

Warner, K. (2010). Global environmental change and migration: Governance challenges. Global environmental change, 20(3), 402-413. doi:10.1016/j.gloenvcha.2009.12.001

World Bank (2018a). Annual Remittances Data (updated as of Dec. 2018). Retrieved from https://www.worldbank.org/en/topic/migrationremittancesdiasporaissues/brief/migrationremittances-data. Accessed 10/10/2019

World Bank (2018b). GDP per capita (current US\$) https://data.worldbank.org/indicator/NY.GDP.PCAP.CD

World Bank (2018c). Migration and Remittances Data. Retrieved from https://www.worldbank.org/en/topic/migrationremittancesdiasporaissues/brief/migrationremittances-data. Accessed 10/10/2019

World Bank (2018d). World Bank Country and Lending Groups. Retrieved from https://datahelpdesk.worldbank.org/knowledgebase/articles/906519. Accessed 10/10/2019

World Bank Group (2019) International migrant stock ( $\%$ of population). Retrieved from https://data.worldbank.org/indicator/SM.POP.TOTL.ZS. Accessed 10/10/2019 